\title{
28 Research Square \\ Drivers of East Asian millennial-scale climate over the past 400,000 years
}

\section{Yoshimi Kubota ( $\nabla$ yoshimi@kahaku.go.jp )}

National Museum of Nature and Science https://orcid.org/0000-0003-2793-6776

\section{Steven Clemens}

Brown University https://orcid.org/0000-0002-1136-7815

\section{Kyung Eun Lee}

Korea Maritime and Ocean University https://orcid.org/0000-0002-1548-9991

\section{Ann Holbourn}

Christian-Albrechts-University

\section{Etsuko Wakisaka}

University of Toyama

\section{Keiji Horikawa}

University of Toyama https://orcid.org/0000-0003-0337-0413

\section{Ryuji Tada}

University of Tokyo

\section{Katsunori Kimoto}

Research Institute for Global Change

\section{Article}

Keywords:

Posted Date: January 12th, 2022

DOI: https://doi.org/10.21203/rs.3.rs-1041978/v1

License: (c) (i) This work is licensed under a Creative Commons Attribution 4.0 International License. Read Full License 


\section{Abstract}

The history of abrupt climate change in East Asia is often discussed from hydroclimate proxies that record the isotopic composition of rainfall. However, the underlying mechanisms remain obscure because water-isotope proxies respond to a wide variety of environmental variables. Here, we investigated millennial-scale climate variability in East Asia over the past 400,000 years using paired foraminiferal oxygen isotope and $\mathrm{Mg} / \mathrm{Ca}$ records from the East Asian continental margin, thereby resolving variance into temperature and rainfall components. We found that the temperature and rainfall variabilities are largely asynchronous, with times when the global climate shifts from interglacial to glacial periods being the notable exception. These findings highlight the importance of both mean global state and magnitude of North Atlantic variability in determining the East Asian climate. Without a strong North Atlantic forcing, the regional feedback system might generate asynchronous temperature and rainfall variations, which is the background climate feature in East Asia.

\section{Main Text}

Abrupt centennial- to millennial-scale climate changes have threatened past civilisations via food shortages, health risks, and societal unrest ${ }^{1}$. Temperature also critically affects human society by influencing agriculture and health. East Asia is among the most densely populated regions on Earth, with increased vulnerability to future climate change. The prominent feature of the East Asian climate is the East Asian summer monsoon (EASM) system, which drives summer rainfall with inherent natural variability including floods and droughts. Long-term predictions of both rainfall and temperature suggest that future warming and increase in precipitation are likely in East Asia ${ }^{2}$; however, these predictions have not yet been substantiated, especially in the EASM region where natural climate variability is substantial ${ }^{3}$. Here, such natural rainfall variability includes processes intrinsic to the atmosphere and ocean as well as air-sea interactions at the regional and local scales ${ }^{4}$. Current climate models fail to replicate realistic multidecadal- to centennial-scale hydroclimate variabilities, suggesting an underestimation of variability over these or longer timescales in fully coupled climate models ${ }^{5}$. Fortunately, geological archives provide valuable records of climate variability over these timescales.

The Late Quaternary is a useful period for constraining the magnitude and timing of millennial-scale (1$10 \mathrm{kyr}$ ) rainfall and temperature variabilities in East Asia, with millennial-scale changes recorded in deepsea sediments from the Sea of Japan ${ }^{6}$, the oxygen isotope $\left(\delta^{18} 0\right)$ signals of Chinese speleothems $\left(\delta^{18} \mathrm{O}_{\mathrm{sp}}\right)^{7,8}$, and East China Sea $(\mathrm{ECS})^{8}$. These recurrent and rapid changes in East Asian water isotope records are considered synchronous with Heinrich events and Dansgaard-Oeschger (DO) oscillations in the North Atlantic ${ }^{7}$. North Atlantic cold intervals (i.e. DO stadials or Heinrich events) are classically viewed as being linked to dry ${ }^{7}$ and $\mathrm{cool}^{9}$ periods in East Asia; however, the extent to which water isotope proxies can independently constrain rainfall and temperature remains a matter of debate, and the timing and magnitude of the changes and phase relationships between these critical climate variables remain unclear on a millennial timescale. 
When speleothem $\mathrm{CaCO}_{3}$ is precipitated under equilibrium conditions, $\delta^{18} \mathrm{O}_{\mathrm{sp}}$ is a function of drip water (rainfall) $\delta^{18} \mathrm{O}$ and cave temperature ${ }^{10}$. Rainfall $\delta^{18} \mathrm{O}$ itself is a complicated function of source area, dynamics along the transport path, local rainfall amount, and cloud condensation parameters ${ }^{11}$. When using these records, a primary impediment to interpreting millennial-scale variability is the lack of a means to decompose water isotope proxies into the key constituents of rainfall amount and surface temperature. However, the $\delta^{18} \mathrm{O}$ signal of calcite from planktonic foraminifera $\left(\delta^{18} \mathrm{O}_{\mathrm{pf}}\right)$ preserved in nearshore marine sediments can be quantitatively partitioned into sea surface temperature (SST) and the $\delta^{18} \mathrm{O}$ of seawater $\left(\delta^{18} \mathrm{O}_{\mathrm{w}}\right)$ using well-established methods of paired $\mathrm{Mg} / \mathrm{Ca}$ and $\delta^{18} \mathrm{O}_{\mathrm{pf}}{ }^{12-14}$. Here, we utilised a suite of high-temporal-resolution ( 270-year) paired planktonic foraminiferal (Globigerinoides ruber sensu stricto (s.s.)) $\mathrm{Mg} / \mathrm{Ca}$ and $\delta^{18} \mathrm{O}_{\mathrm{pf}}$ records spanning the past 400 thousand years (ka) from the northern ECS (IODP Site U1429: $31.62^{\circ} \mathrm{N}, 129^{\circ} \mathrm{E}, 732 \mathrm{~m}$ below sea level) to investigate millennial-scale climate variability (Fig. S1). Our precisely paired $1,413 \mathrm{Mg} / \mathrm{Ca}{ }^{15}$ and $\delta^{18} \mathrm{O}_{\mathrm{pf}}{ }^{8}$ dataset allowed us to directly compare SST and $\delta^{18} \mathrm{O}_{\mathrm{w}}$ with no time lag. Thus, we build on previous research in which almost half of the $\mathrm{Mg} / \mathrm{Ca}$ data points corresponding to the same horizons as the available $\delta^{18} \mathrm{O}_{\mathrm{pf}}$ record were interpolated ${ }^{8}$.

The ECS is a marginal basin located at the rim of the western North Pacific and receives $90 \%$ of its fluvial input from Yangtze (Changjiang) River, which results in a strong correlation between the runoff and the summer sea surface salinity (SSS) in the northern $\operatorname{ECS}^{16} . \delta^{18} \mathrm{O}_{\mathrm{w}}$ varies as a function of rainfall and runoff $^{8}$ and is linearly correlated with the SSS in the ECS today ${ }^{17}$. Using G. ruber s.s., the most abundant surface-dweller in warmer months ${ }^{18}$, the core top and late Holocene $\mathrm{Mg} / \mathrm{Ca}$-derived SST was determined to be $\sim 26^{\circ} \mathrm{C}$ close to site $\mathrm{U} 1429$, indicating that the records from this species primarily reflect variability during the warmer months of the year.

\section{Results And Discussion}

The SST and $\delta^{18} \mathrm{O}_{\mathrm{w}}$ records at Site U1429 were high-pass filtered to eliminate orbital-scale components to investigate the characteristics of abrupt variance (1-10 kyr periodicity) (Fig. 1C, Materials and Methods, Fig. S2, S3). We applied wavelet analysis to assess the coherence and phase relationships in the time-frequency space between SST and $\delta^{18} \mathrm{O}_{w}{ }^{19}$ (Fig. 1D). Considering the following reasons, we interpreted the observed millennial-scale variability as being dominated by changes in the freshwater influx from Yangtze River. The factors that potentially influence past $\delta^{18} \mathrm{O}_{\mathrm{w}}$ values are ocean mixing, river runoff, and the $\delta^{18} \mathrm{O}_{\mathrm{w}}$ endmember ${ }^{8,20}$. Shoreline migration and changes in geographic configuration due to sea-level change may alter the extent of mixing between $\delta^{18} \mathrm{O}$-enriched seawater from the Kuroshio Current and $\delta^{18} \mathrm{O}$-depleted river water on the orbital timescales ${ }^{8}$ but these factors are minimal on the millennial timescales. A high variability in the $\delta^{18} \mathrm{O}_{\mathrm{w}}$ endmember in the western tropical Pacific (WTP) source region and freshwater $\delta^{18} \mathrm{O}_{\mathrm{w}}$ itself may obscure changes in the freshwater influx from Yangtze 
River to the ECS. These $\delta^{18} \mathrm{O}_{w}$ endmembers have little influence on $\delta^{18} \mathrm{O}_{w}$ variability in the $\mathrm{ECS}^{21}$, although this has only been assessed for the Marine Isotope Stage (MIS) $3^{21}$ owing to a lack of highresolution data in the WTP. Nonetheless, the situation must be similar during interglacials and other glacials considering that $\delta^{18} \mathrm{O}_{\mathrm{w}}$ endmember variability in the source regions is similar to or less than MIS 3 , as indicated by the Chinese $\delta^{18} \mathrm{O}_{\mathrm{sp}}$ record for the freshwater $\delta^{18} \mathrm{O}_{\mathrm{w}}$ endmember ${ }^{22}$. Therefore, freshwater influx from Yangtze River induced by basin-wide precipitation is considered the main factor influencing the millennial-scale $\delta^{18} \mathrm{O}_{\mathrm{w}}$ signal at Site U1429.

The wavelet analysis revealed that the coherence between SST and $\delta^{18} \mathrm{O}_{\mathrm{w}}$ has varied over the last 400 ka. SST and $\delta^{18} \mathrm{O}_{\mathrm{w}}$ tended to be synchronous in the later stages of interglacials from the early through to middle glacial periods (from early MIS 3 through to late MIS 5, from middle MIS 6 through to late MIS 7 , and from early MIS 8 through to late MIS 9), whereas SST and $\delta^{18} \mathrm{O}_{\mathrm{w}}$ were mostly uncoupled during full interglacials and full glacials. In the youngest coherent interval ( 40-110 ka), synchronous variations become recognisable from $\sim 110 \mathrm{ka}$ (late interglacial) and intermittently persist until $40 \mathrm{ka}$ (middle glacial). In contrast, during the full glacial interval after $40 \mathrm{ka}$, SST and $\delta^{18} \mathrm{O}_{\mathrm{w}}$ in the ECS tended to be decoupled. Similar trends were found during MIS 6-7 and MIS 8-9. At intervals of high coherence, the phase indicates that drying (an increase in $\delta^{18} \mathrm{O}_{\mathrm{w}}$ ) was concomitant with cooling ( $180^{\circ}$ phase lag) or slightly lagged by $\sim 0.5 \mathrm{ka}$ or less. This negative correlation between SST and $\delta^{18} \mathrm{O}_{\mathrm{w}}$ (i.e. cooling and increasing salinity) is also evident in a direct comparison between the SST and $\delta^{18} \mathrm{O}_{\mathrm{w}}$ time-series (Fig. $1 \mathrm{C}$ and S4-S7); near-simultaneous millennial-scale responses were observed during Heinrich events 5, 6, 7a, $8,9,10$, and 11 during MIS 3 through to late MIS 5 ( 40-110 ka), and abrupt climate events between the middle MIS 6 to late MIS 7 ( 160-210 ka) and between early MIS 8 and late MIS $9(\sim 290-320 \mathrm{ka})$ (Fig. 1). A relatively broad interval of high coherence with high confidence was also found in early MIS 7 $(\sim 230-250 \mathrm{ka})$, where the phase relationship is $\sim 180^{\circ}$ opposite to the other intervals, suggesting a different forcing mechanism.

We infer that the ECS SST and $\delta^{18} \mathrm{O}_{\mathrm{w}}$ signals reflect different climate forcings or internal feedbacks during intervals of low coherence but respond to similar mechanisms during times of high coherence. The apparent link between the degree of coupling and glacial state implies that aspects of orbital-scale forcing, such as insolation, atmospheric $\mathrm{CO}_{2}$ concentrations, and ice-sheet extent, might be involved. However, a comparison between Northern Hemisphere local insolation, wherein the precession cycle is the most prominent, and the ECS wavelet coherence does not show similarity (Fig. 1B, 1C). This implies that orbital configuration and the associated local insolation $\left(31^{\circ} \mathrm{N}\right)$ changes have little effect on the coherence pattern. For atmospheric $\mathrm{CO}_{2}$ and ice volume, the high coherence times correspond to 'intermediate' atmospheric $\mathrm{CO}_{2}$ levels and ice volume conditions, which we define as an ice volume equivalent to a -10 to $-90 \mathrm{~m}$ reduction in the sea level, including both middle-late interglacial and earlymiddle glacial periods. 
To consider the possible linkage between the intermediate glacial condition and the high coherence between $\delta^{18} \mathrm{O}_{\mathrm{w}}$ and temperature in the ECS, we examined the changes in the spectral power of millennialscale variance in the North Atlantic palaeoceanographic record as a measure of frequency and magnitude of abrupt hemispheric climate changes. A comparison between coherence in the ECS record and the wavelet spectrum of the relative abundance of Neogloboquadrina pachyderma sinistral at ODP Site $983^{23}$ (see Methods) revealed some similarities; periods of high coherence corresponded to a high spectral power in the North Atlantic record (Fig. 1D, 1E). The high spectral power in the North Atlantic wavelet reflects strong millennial-scale climate events, such as Heinrich events and DO oscillations ${ }^{24}$. Thus, we hypothesise that the magnitude and duration of Atlantic millennial-scale perturbations have a strong influence on the synchronicity of SST and $\delta^{18} \mathrm{O}_{w}$ in the ECS. Specifically, a strong period of Atlantic variability is required to produce coherent variations between these proxies in the ECS. Indeed, we identified counterparts in the North Atlantic for all the ECS cooling/drying events during the highcoherence intervals (dashed lines in Figs. S4-S7), indicating that both SST and $\delta^{18} \mathrm{O}_{\mathrm{w}}$ are paced by events in the North Atlantic.

Modelled climate instability in response to abrupt changes in the Atlantic Meridional Overturning Circulation (AMOC) under different global climate states shows that the intermediate glacial state (the 15 ka condition in this case) is the most favourable for generating millennial-scale variability, whereby both Northern Hemisphere ice sheets and atmospheric $\mathrm{CO}_{2}$ concentration are crucial factors ${ }^{24}$. Based on the same model, the signal from abrupt events in the North Atlantic propagates on a hemispheric scale within a few hundred years ${ }^{24}$. Therefore, compared with other mean states, the intermediate glacial condition is more conducive to simultaneous cooling and drying in East Asia.

These findings indicate that abrupt climate change in East Asia is driven by two primary mechanisms: Atlantic perturbations and regional variability (feedbacks) primarily dependent on the magnitude of North Atlantic events, and the mean global climate state. To further examine whether the amplitude of East Asian climate variability is dependent on these forcings, we calculated the standard deviation for each glacial condition (Methods, Fig. S8), that is, full interglacial (>-10 m sea level), intermediate glacial ( -10 to $-90 \mathrm{~m})$, and full glacial $(<-90 \mathrm{~m})$. We found the highest standard deviation under the intermediate glacial state for both SST and $\delta^{18} \mathrm{O}_{\mathrm{w}}$. Thus, the magnitudes of climate events in East Asia tend to increase when forced from outside the region. We hypothesise that strong climatic events in the North Atlantic, such as Heinrich events, quickly propagate worldwide, affecting East Asian climate variability during intermediate glacial states. Nevertheless, a relatively high climate variability in the ECS is also evident during full interglacials and glacial maxima, suggesting that regional (internal) sources of variability are also important. For example, during full interglacial and glacial states, regional dynamics tended to dominate the Atlantic climate forcing or respond differently at certain times, such as during early MIS 7 ( 230-250 ka) when SST and $\delta^{18} \mathrm{O}_{\mathrm{w}}$ were positively correlated, indicating warming and increasing salinity. This positive correlation can be explained by the changes in the extent of mixing between cold, diluted water formed near Yangtze River mouth and warm, saline water from the Kuroshio 
Current. A positive correlation between SST and $\delta^{18} \mathrm{O}_{\mathrm{w}}$ is also observed during the Holocene, the early stage of the last deglaciation ${ }^{25}$, and at the maxima of MIS 5 (Fig. 1D), suggesting that ocean mixing has dominated during some full interglacial and glacial periods. In contrast, the periods with a negative correlation between SST and $\delta^{18} \mathrm{O}_{\mathrm{w}}$ cannot be reasonably explained by ocean mixing. Rather, we interpret this relationship as reflecting the dominance of the atmospheric signal over ocean mixing.

The Heinrich events that occurred during full glacial stages (e.g., $\mathrm{H}-1$ and $\mathrm{H}-2$ ) are not correlated with the low SST and high $\delta^{18} \mathrm{O}_{\mathrm{w}}$ signals in the ECS; however, MIS 6 is an exception, when SST and $\delta^{18} \mathrm{O}_{\mathrm{w}}$ are negatively correlated with high coherence, especially around $\mathrm{H}-11$. Thus, we infer that the mean temperature state during full glacial stages is critical for explaining millennial-scale variability in East Asia, as the full glacial period of MIS 6 was slightly $\left(\sim 1^{\circ} \mathrm{C}\right)$ warmer than other glacial stages based on the ECS Mg/Ca-SST record (Figs. S4-S7).

We directly compared our ECS data with the Greenland (NGRIP) record over the last 100 ky to elucidate the mechanism of signal propagation from the North Atlantic to East Asia. Specifically, we performed wavelet coherence analysis to clarify parameters in the ECS record that are more coherent with the Greenland isotope record (Fig. 2). The ECS $\delta^{18} \mathrm{O}_{\mathrm{pf}}$ and Greenland $\delta^{18} \mathrm{O}$ records show the largest coherent area. The ECS SST and Greenland $\delta^{18} \mathrm{O}$ records indicate a similar high degree of coherence, whereas the ECS $\delta^{18} O_{w}$ and Greenland $\delta^{18} O$ records show the least coherence (Fig. 2). The high level of coherence between the ECS SST and Greenland $\delta^{18} \mathrm{O}$ likely stems from the faster propagation of the temperature signal from the North Atlantic (via the Westerlies) relative to a more local and complex response to rainfall. In this regard, rainfall variability reflects inherent natural variability more so than temperature, which is dominated by external signals (from the North Atlantic) only during high-magnitude events, such as Heinrich events. This hypothesis and more in-depth investigation of the underlying mechanisms could be tested using a coupled climate model simulation that embeds water $\delta^{18} 0$ changes with different greenhouse gas, ice-volume, and sea-level boundary conditions.

Overall, our results provide an important perspective for interpreting $\delta^{18} \mathrm{O}_{\mathrm{sp}}$ records in the ECS. In particular, our records have the advantage of covering the interval from 260 to $310 \mathrm{ka}$, when millennialscale variability is not well resolved in the $\delta^{18} \mathrm{O}_{\mathrm{sp}}$ record. Indeed, our $\delta^{18} \mathrm{O}_{\mathrm{pf}}$ record is well correlated with the $\delta^{18} \mathrm{O}_{\mathrm{sp}}$ record on a millennial scale except for 260-310 ka. The SST and $\delta^{18} \mathrm{O}_{\mathrm{w}}$ records also show strong correlations with $\delta^{18} \mathrm{O}_{\mathrm{sp}}$, although to a less extent (Fig. S9). Based on our wavelet coherence analysis of the three ECS records $\left(\delta^{18} \mathrm{O}_{\mathrm{pf}}, \mathrm{SST}\right.$, and $\left.\delta^{18} \mathrm{O}_{\mathrm{w}}\right)$ vs. $\delta^{18} \mathrm{O}_{\mathrm{sp}}$, coherence was reduced once the sea level and temperature effects were removed from the $\delta^{18} \mathrm{O}_{\mathrm{pf}}$ signal, although some high coherence areas remain in the intermediate glacial states between $\delta^{18} \mathrm{O}_{\mathrm{w}}$ and $\delta^{18} \mathrm{O}_{\mathrm{sp}}$ (Fig. S10). This indicates that both SST and $\delta^{18} \mathrm{O}_{\mathrm{w}}$ are essential components of the $\delta^{18} \mathrm{O}_{\mathrm{sp}}$ signal, and that the global condition, such as sea level, is the crucial factor affecting local rainfall variability in East Asia. Overall, our findings 
highlight the importance of the global background condition in determining the behaviour of the East Asian climate, offering a valuable baseline for predicting future climate change.

\section{Declarations}

Acknowledgements: This research used samples and data provided by the Integrated Ocean Drilling Program (IODP). We acknowledge the analytical support of H. Yamamoto, T. Omura, Y. Sato, M. Takada, and manuscript preparation assistance from T. Umeno and M. Yagishita. We are grateful to T. Irino for helpful discussions and comments on the manuscript. Funding for this work was provided by JSPS KAKENHI JP15K21656, JSPS KAKENHI JP26870215, JSPS JPMXS05R2900001, IODP Exp. 346 After Cruise Research Program, Japan Agency for Marine-Earth Science and Technology, Mutsu Institute for Oceanography, Japan Agency for Marine-Earth Science and Technology, and Micropaleontological Reference Center, National Museum of Nature and Science, Tsukuba, Japan.

Author contributions: Y.K., S.C., K.E.L., R.T. designed this study. Y.K., E.W., K.H., K.K. carried out Mg/Ca analyses. All authors contributed to the data interpretation and commented on the final manuscript.

Competing interests: The authors declare no competing interests.

Correspondence and requests for materials should be addressed to Y.K.

\section{References}

1. McMichael, A. J. Insights from past millennia into climatic impacts on human health and survival. Proceedings of the National Academy of Sciences 109, 4730-4737 (2012).

2. IPCC. Climate change 2014: Synthesis Report. (Cambridge University Press, 2014). doi:10.1017/СВ09781107415416

3. Xie, S.-P. et al. Towards predictive understanding of regional climate change. Nature Climate Change 5, 921-930 (2015).

4. Deser, C., Phillips, A., Bourdette, V. \& Teng, H. Uncertainty in climate change projections: the role of internal variability. Climate Dynamics 38, 527-546 (2010).

5. Loope, G., Thompson, D. \& Overpeck, J. The spectrum of Asian Monsoon variability: A proxy system model approach to the hydroclimate scaling mismatch. Quat Sci Rev 240, 106362 (2020).

6. Tada, R., Irino, T. \& Koizumi, I. Land-ocean linkages over orbital and millennial timescales recorded in late Quaternary sediments of the Japan Sea. Paleoceanography 14, 236-247 (1999).

7. Wang, Y. J. et al. A high-resolution absolute-dated late Pleistocene Monsoon record from Hulu Cave, China. Science 294, 2345-2348 (2001).

8. Clemens, S. C. et al. Precession-band variance missing from East Asian monsoon runoff. Nature Commun 9, 3364 (2018). 
9. Sone, T. et al. Holocene stalagmite oxygen isotopic record from the Japan Sea side of the Japanese Islands, as a new proxy of the East Asian winter monsoon. Quat Sci Rev 75, 150-160 (2013).

10. Hu, C. et al. Quantification of Holocene Asian monsoon rainfall from spatially separated cave records. Earth Planet Sci Lett 266, 221-232 (2008).

11. Dayem, K. E., Molnar, P., Battisti, D. S. \& Roe, G. H. Lessons learned from oxygen isotopes in modern precipitation applied to interpretation of speleothem records of paleoclimate from eastern Asia. Earth Planet Sci Lett 295, 219-230 (2010).

12. Lea, D. W., Mashiotta, T. A. \& Spero, H. J. Controls on magnesium and strontium uptake in planktonic foraminifera determined by live culturing. Geochimica et Cosmochimica Acta 63, 2369-2379 (1999).

13. Bemis, B. E., Spero, H. J., Bijma, J. \& Lea, D. W. Reevaluation of the oxygen isotopic composition of planktonic foraminifera: Experimental results and revised paleotemperature equations.

Paleoceanography 13, 150-160 (1998).

14. Mashiotta, T. A., Lea, D. W. \& Spero, H. J. Glacial-interglacial changes in Subantarctic sea surface

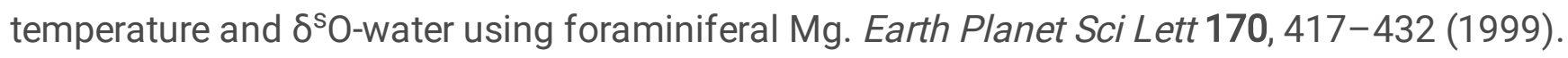

15. Lee, K. E. et al. Roles of insolation forcing and $\mathrm{CO}_{2}$ forcing on Late Pleistocene seasonal sea surface temperatures. Nature Commun 1-13 (2021). doi:10.1038/s41467-021-26051-y

16. Delcroix, T. \& Murtugudde, R. Sea surface salinity changes in the East China Sea during 1997-2001: Influence of the Yangtze River. J. Geophys. Res. 107, 8008 (2002).

17. Horikawa, K., Kodaira, T., Zhang, J. \& Murayama, M. $\delta{ }^{18} \mathrm{O}_{\mathrm{sw}}$ estimate for Globigerinoides ruber from core-top sediments in the East China Sea. Prog Earth Planet Sci 2, (2015).

18. Xu, X., Yamasaki, M., Oda, M. \& Honda, M. C. Comparison of seasonal flux variations of planktonic foraminifera in sediment traps on both sides of the Ryukyu Islands, Japan. Mar Micropaleonto/ 58, 45-55 (2005).

19. Grinsted, A., Moore, J. C. \& Jevrejeva, S. Application of the cross wavelet transform and wavelet coherence to geophysical time series. Nonlinear Processes in Geophysics 11, 561-566 (2004).

20. Kubota, Y., Tada, R. \& Kimoto, K. Changes in East Asian summer monsoon precipitation during the Holocene deduced from a freshwater flux reconstruction of the Changjiang (Yangtze River) based on the oxygen isotope mass balance in the northern East China Sea. Clim Past 11, 265-281 (2015).

21. Kubota, Y., Kimoto, K., Tada, R., Uchida, M. \& Ikehara, K. Millennial-scale variability of East Asian summer monsoon inferred from sea surface salinity in the northern East China Sea (ECS) and its impact on the Japan Sea during Marine Isotope Stage (MIS) 3. Prog Earth Planet Sci 6, 39 (2019).

22. Cheng, H. et al. The Asian monsoon over the past 640,000 years and ice age terminations. Nature 534, 640-646 (2016).

23. Barker, S. et al. Icebergs not the trigger for North Atlantic cold events. Nature 520, 333-336 (2015).

24. Dome Fuji Ice Core Project Members: et al. State dependence of climatic instability over the past 720,000 years from Antarctic ice cores and climate modeling. Sci. Adv. 3, e1600446-21 (2017). 
25. Kubota, Y. et al. Variations of East Asian summer monsoon since the last deglaciation based on $\mathrm{Mg} / \mathrm{Ca}$ and oxygen isotope of planktic foraminifera in the northern East China Sea. Paleoceanography 25, PA4205 (2010).

26. Waelbroeck, C. et al. Sea-level and deep water temperature changes derived from benthic foraminifera isotopic records. Quat Sci Rev 21, 295-305 (2002).

27. Lisiecki, L. E. \& Stern, J. V. Regional and global benthic $\delta^{18} 0$ stacks for the last glacial cycle. Paleoceanography 31, 1368-1394 (2016).

28. Svensson, A. et al. A 60000 year Greenland stratigraphic ice core chronology. Clim. Past 4, 47-57 (2008).

29. Obrochta, S. P., Yokoyama, Y., Morén, J. \& Crowley, T. J. Conversion of GISP2-based sediment core age models to the GICC05 extended chronology. Quaternary Geochronology 20, 1-7 (2014).

30. Seierstad, I. K. et al. Consistently dated records from the Greenland GRIP, GISP2 and NGRIP ice cores for the past 104 ka reveal regional millennial-scale $\delta^{18} 0$ gradients with possible Heinrich event imprint. Quat Sci Rev 106, 29-46 (2014).

\section{Methods}

\section{Oxygen Stable Isotopes and $\mathrm{Mg} / \mathrm{Ca}$ measurements}

The published planktonic foraminifer oxygen isotope record $\left(\delta^{18} \mathrm{O}_{\mathrm{pf}}\right)$ from IODP Site U1429 in ${ }^{8}$ was used for this study. Sediment material of U1429 was sampled at $5 \mathrm{~cm}$ resolution from 0-25 m below sea floor (mbsf), at 5 or $10 \mathrm{~cm}$ resolution from 25 to $35 \mathrm{mbsf}$, and at 5, 10, or $15 \mathrm{~cm}$ resolution from 35 to 181 mbsf. Samples were freeze-dried, wet-sieved at $63 \mu \mathrm{m}$, and dried in an oven at $50^{\circ} \mathrm{C}$. The $>63 \mu \mathrm{m}$ fraction was then sieved into four size fractions, 63-150, 150-250, 250-355, and >355 $\mu \mathrm{m}$. Approximately 30-50 individual Globigerinoides ruber (white, sensu stricto) were picked from the 250-355 $\mu \mathrm{m}$ size fraction for both stable isotope $\left(\delta^{18} \mathrm{O}, \delta^{13} \mathrm{C}\right)$ and $\mathrm{Mg} / \mathrm{Ca}$ analysis. Approximately 20 and 30 individuals were used for $\mathrm{Mg} / \mathrm{Ca}$ and stable isotope analyses respectively. Samples for stable isotope analyses were sonicated in ethanol to remove fine clays, homogenised, and subsampled $\left(\sim 80 \mu \mathrm{g} \mathrm{CaCO}_{3}\right)$ for analysis on the Brown University MAT 252 IRMS coupled to a Kiel III carbonate device. Replicate analysis of homogenised foraminifera samples $(n=42,1 \sigma)$ yields \pm 0.05 for $\delta^{18} O$ and \pm 0.03 for $\delta^{13} \mathrm{C}$. All analyses are reported as \%o VPDB.

$\mathrm{Mg} / \mathrm{Ca}$ analysis of $\mathrm{G}$. ruber sensu stricto (s.s.) was carried out for U1429, using splits of the same $G$. rubers.s. fraction used to measure planktonic $\delta^{18} 0$. Prior to measurement, foraminiferal tests were cleaned following the reductive approach, modified from ${ }^{31}$, as detailed in ${ }^{32}$ and ${ }^{20}$. The metal/Ca ratios of most of samples were determined with a Thermo Scientific ELEMENT XR, a double focusing sector field inductively coupled plasma mass spectrometer (ICP-MS) at the Mutsu Institute for Oceanography (MIO). The elements ${ }^{24} \mathrm{Mg}$ and ${ }^{44} \mathrm{Ca}$, measured in a middle resolution mode, were used to determine $\mathrm{Mg} / \mathrm{Ca}$ for the samples analysed at the MIO. The precision of the measurement was checked by replicate 
measurement (every five to six samples) of working standards produced at MIO from high purity standards (1000 $\pm 3 \mathrm{mg} / \mathrm{L}$ ) SPEX Claritas PPT. Relative standard deviation (RSD) of the long-term measurement of the working standards was less than $2.6 \%$ at $\mathrm{MIO}$. The accuracy of $\mathrm{Mg} / \mathrm{Ca}$ ratios were confirmed by analyses of a $\mathrm{CaCO}_{3}$ reference standard, coral Porites standard material JCp-1, whose $\mathrm{Mg} / \mathrm{Ca}$ values was internationally determined $(4.199 \pm 0.065 \mathrm{mmol} / \mathrm{mol})$. The measured $\mathrm{Mg} / \mathrm{Ca}$ of JCp-1 was $4.161 \pm 0.064(1 \sigma, \mathrm{N}=24) \mathrm{mmol} / \mathrm{mol}$ at $\mathrm{MIO}$. In addition to $\mathrm{Mg} / \mathrm{Ca}, \mathrm{Mn} / \mathrm{Ca}$ was measured to monitor the contamination by diagenetic coating. $\mathrm{Mn} / \mathrm{Ca}$ of $99 \%$ of the samples were less than $0.5 \mathrm{mmol} / \mathrm{mol}$. As there was no positive relationship between $\mathrm{Mg} / \mathrm{Ca}$ and $\mathrm{Mn} / \mathrm{Ca}(>0.5 \mathrm{mmol} / \mathrm{mol})$, we did not eliminate high $\mathrm{Mn} / \mathrm{Ca}$ samples. In order to increase the time resolution, we analysed 557 samples in addition to the $\mathrm{Mg} / \mathrm{Ca}$ data published in ${ }^{8}$. We used $1,413 \mathrm{Mg} / \mathrm{Ca}$ data in total that has a paired $\delta^{18} \mathrm{O}_{\mathrm{pf}}$ for the seawater $\delta^{18} \mathrm{O}$ reconstruction described in a following section.

Sixteen samples were repicked and rerun for duplication test for $\mathrm{Mg} / \mathrm{Ca}$ in $\mathrm{MIO}$. The average of the difference of $\mathrm{Mg} / \mathrm{Ca}$ between duplicates was $0.086 \pm 0.149(1 \sigma) \mathrm{mmol} / \mathrm{mol}$, which was equivalent to 0.48 $\pm 0.36^{\circ} \mathrm{C}$. The effect of preferential removal of $\mathrm{Mg}^{2+}$ from foraminiferal calcite on $\mathrm{Mg} / \mathrm{Ca}$ values due to dissolution on the seafloor (e.g. ${ }^{33}$, and references therein) is likely negligible because the water depth of the core site $(732 \mathrm{~m}$ ) is well above the modern lysocline (approximately $1600 \mathrm{~m}$ ) in East China Sea (ECS) and over $800 \mathrm{~m}$ above the depth at which dissolution impacts the $\mathrm{Mg} / \mathrm{Ca}$ temperature estimation in this region.

\section{Age model, SST and Local seawater $\delta^{18} \underline{0 \text { reconstruction }}$}

We used the age model established in ${ }^{8}$. Sea Surface Temperature (SST) and $\delta^{18} O$ of local seawater $\left(\delta^{18} \mathrm{O}_{w}\right)$ is derived using Paleo-Seawater Uncertainty Solver (PSU Solver) ${ }^{34}$ on the set of 1413 paired samples. We applied the same methodology used in ${ }^{8}$ to reconstruct SST and $\delta^{18} \mathrm{O}_{\mathrm{w}}$. As no regional $\mathrm{Mg} / \mathrm{Ca}$ calibration exists for the ECS, we employ the $\mathrm{Mg} / \mathrm{Ca}$ calibration of ${ }^{35}$ that utilises all available culture data in a multivariate calibration that accounts for both salinity and temperature. We utilise the seawater $\delta^{18} \mathrm{O}$-temperature relationship (low light) of ${ }^{13}$, the ECS G. ruber core top seawater $\delta^{18} \mathrm{O}$-salinity relationship of ${ }^{32}$, and the global sea level curve of ${ }^{26}$. Instead of using the Waelbroeck et al. curve directly, the low pass filtered (removing frequencies higher than $1 / 10 \mathrm{ky}^{-1}$ ) U1429 benthic $\delta^{18} \mathrm{O}$ record was scaled to match the Waelbroeck et al. curve such that the age model and high-resolution sampling at U1429 remains intact.

\section{High pass filter and wavelet coherence}

Prior to the process of high pass filter, each data set were linearly interpolated at every 100-year interval. The built-in function of high pass filter in MATLAB ${ }^{\circledR}$ R2020a was used to remove the orbital scale cyclicity (> $10 \mathrm{ky}$ ). Wavelet coherence was obtained using the function 'wtc' on MATLAB ${ }^{\circledR}$ R2020a ${ }^{19}$. The statistical significance level of the wavelet coherence is estimated using Monte Carlo methods ${ }^{19}$. For the 
comparison between the ECS and Chinese cave $\delta^{18} 0$, we used the composite $\delta^{18} 0$ record in ${ }^{22}$. For the comparison between the ECS and Greenland, we used the North GRIP (NGRIP) ice core results ${ }^{29,30}$.

\section{Standard deviation for each glacial state}

We performed F-test to test the null hypothesis that the two data set comes from normal distributions with the same variance against the alternative that the population variance of one sample set is greater than that of the other. The F-test was conducted using the function 'vartest2' on MATLAB ${ }^{\circledR}$ R2020a. For all combination between full interglacial (> $-10 \mathrm{~m}$ of sea level), intermediate glacial $(-10 \mathrm{~m}--90 \mathrm{~m})$ and full glacial $(<-90 \mathrm{~m})$, the null hypothesis was rejected at the $5 \%$ significance level $(p<0.0001)$. These results indicate that the variance in intermediate glacial state is the greatest for both SST and $\delta^{18} \mathrm{O}_{\mathrm{w}}$. The standard deviations for each glacial state were illustrated in Fig. S9. We also calculated the standard deviation for each glacial-interglacial cycle (Fig. S8), where the standard deviation was calculated every $20 \mathrm{~m}$ of sea level.

Data and materials availability: All data necessary to assess the validity of this research will be presented in the World Data Service for Paleoclimatology, National Centers for Environment Information, National Oceanic and Atmospheric Administration.

\section{Methods References}

31. Boyle, E. A. \& Keigwin, L. D. Comparison of Atlantic and Pacific paleochemical records for the last 215,000 years: changes in deep ocean circulation and chemical inventories. Earth Planet Sci Lett 76, 135-150 (1985).

32. Horikawa, K., Kodaira, T., Zhang, J. \& Murayama, M. $\delta{ }^{18} \mathrm{O}_{\mathrm{sw}}$ estimate for Globigerinoides ruber from core-top sediments in the East China Sea. Prog Earth Planet Sci 2, (2015).

33. Dekens, P. S., Lea, D. W., Pak, D. K. \& Spero, H. J. Core top calibration of Mg/Ca in tropical foraminifera: Refining paleotemperature estimation. Geochemistry, Geophysics, Geosystems 3, 1-29 (2002).

34. Thirumalai, K., Quinn, T. M. \& Marino, G. Constraining past seawater $\delta^{18} \mathrm{O}$ and temperature records developed from foraminiferal geochemistry. Paleoceanography 31, 1409-1422 (2016).

35. Tierney, J. E., Pausata, F. S. R. \& deMenocal, P. Deglacial Indian monsoon failure and North Atlantic stadials linked by Indian Ocean surface cooling. Nature Geosci 9, 46-50 (2015).

\section{Supplementary Information References}

36. Locarnini, R. A. et al. in World Ocean Atlas (ed. Levitus, S.) 1, 1-40 (2013). 
37. Zweng, M. M. et al. in World Ocean Atlas (ed. Levitus, S.) 2, 1-39 (2013).

38. Martrat, B. et al. Four Climate Cycles of Recurring Deep and Surface Water Destabilizations on the Iberian Margin. Science 317, 502-507 (2007).

\section{Figures}

\section{Figure 1}

Palaeoceanographic records from IODP Site U1129 compared with local insolation change, global, and North Atlantic records. (A) Benthic foraminiferal $\delta^{18} \mathrm{O}$ at Site U1429 (grey) ${ }^{8}$ and global sea level (red) ${ }^{26}$, (B) summer $\left(21^{\text {st }}\right.$ June $)$ insolation at $31^{\circ} \mathrm{N}$, (C) high-pass filtered U1429 local seawater $\delta^{18} \mathrm{O}\left(\delta^{18} \mathrm{O}_{\mathrm{w}}\right)$ (green), U1429 SST (red) with Heinrich events in blue compared with the global sea level, (D) squared wavelet coherence between U1429 SST and $\delta^{18} \mathrm{O}_{w}$, and (E) continuous wavelet power spectra of relative abundance of $N$. pachyderma sinistral at Site 983 in the high-latitude North Atlantic ${ }^{23}$. The blue dashed lines in (A) represent sea levels of -10 and $-90 \mathrm{~m}$. YD and $\mathrm{H} 1-\mathrm{H} 12$ denote the Younger Dryas and Heinrich events $1-12$ in the North Atlantic, respectively ${ }^{27}$. The $5 \%$ significance level against red noise is shown as a thick contour in (D) and (E). The arrows represent the relative phase relationship with inphase pointing right, anti-phase pointing left, and SST leading $\delta^{18} \mathrm{O}_{\mathrm{w}}$ by $90^{\circ}$ pointing straight down ${ }^{19}$. The coherence intervals are highlighted in yellow bars in (A), (B), and (C). The yellow dashed lines in (D) and $(E)$ indicate the start and end of the coherent intervals in East China Sea (ECS). 
A)

Wavelet Coherence (U1429 $\delta^{18} \mathrm{O}$ vs NGRIP)

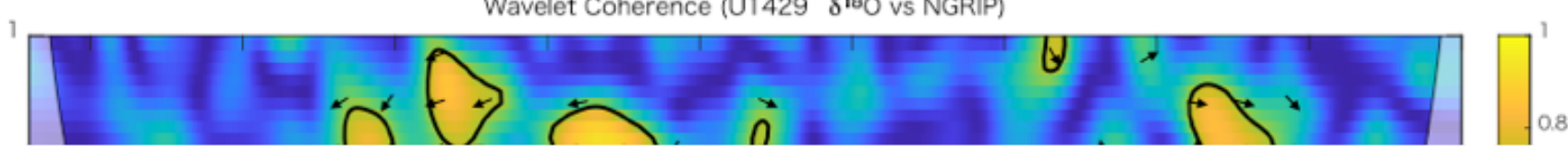

Figure 2

Squared wavelet coherence showing the relationship between East Asia and North Atlantic. Squared wavelet coherence (A) between U1429 planktonic foraminiferal $\delta^{18} \mathrm{O}\left(\delta^{18} \mathrm{O}_{\mathrm{pf}}\right)$ and Greenland NGRIP ${ }^{28-30}$, (B) between U1429 SST and Greenland NGRIP, and (C) between U1429 local seawater $\delta^{18} O\left(\delta^{18} O_{w}\right)$ and Greenland NGRIP. The thick contour and arrows are the same as in Fig. 1. 


\section{Supplementary Files}

This is a list of supplementary files associated with this preprint. Click to download.

- FigS1lowresolution.pdf

- FigS2.pdf

- FigS3errord180wSST.pdf

- FigS4Comparison1.pdf

- FlgS5Comparison2.pdf

- FigS6Comparison3.pdf

- FigS7Comparison4.pdf

- FigS8revised.pdf

- FigS9d180spvsU1429.pdf

- FigS10.pdf 